\title{
The Role of Motivation in Second Language Learning in King Khalid University, Saudi Arabia
}

\author{
Rafiq Shamiry \\ King Khalid University, Abha, Saudi Arabia \\ Mohammad Al Fuad \\ King Khalid University, Abha, Saudi Arabia
}

\begin{abstract}
This paper attempts to shed light on Saudi college students' internal motivational set up and how it negatively impacts their learning outcomes at the tertiary level at King Khalid University. To investigate that, a questionnaire that consists of ten questions was conducted on 90 (ninety) students selected from level four and eight in the Department of English of the same university. The responses of the learners indicate that the majority of the respondents are not highly motivated and chose English as a major- for their B.A. courseagainst their will as there were no other alternatives for several reasons. The results show- not surprisingly though- that most of the students are driven by extrinsic motivation to study English in order to get good jobs. The statistics obtained from the Department, of deprived and withdrawn students are quite high and that confirm the researchers' hypothesis of students' demotivation in the Department of English. Finally, researchers have suggested some remedial academic initiatives to help these undergraduate Saudi students in the Department of English at King Khalid University to overcome the difficulties and problems resulting from extrinsic motivation and showing ways of attaining positive (intrinsic) motivational make up that initiates true, life-long learning.
\end{abstract}

Index Terms - intrinsic, extrinsic, King Khalid University, motivation, Saudi Arabia

\section{INTRODUCTION}

It is not uncommon to find that many college level students around the world often suffer from lack of motivation. Saudi students are no different. Moving from the easy-going high schools, they suddenly find it quite challenging to be able to pursue their academic goals at the university, where individual learning is strongly emphasized. They start having doubts about their capabilities for being successful. An article published on Forbes.com confirms students who are bored or inattentive or who put little effort to schoolwork are unlikely to benefit from better standards, curriculum, and instruction unless schools, teachers, and parents take steps to address their lack of motivation, the research papers at the Center on Education Policy (CEP) at George Washington University conclude. On the other hand, students who are motivated to learn have higher achievement, show better understanding of the concepts they are taught, are more satisfied with school, and have lower dropout rates, according to a variety of studies reviewed by Edward Deci and colleagues (Crotty, 2013). The earlier stage in the above-mentioned scenario is more than true to the situations of most of the Saudi college students.

Hence, it becomes important to investigate why these students lose their high hopes and motivation. This study shows that the remedies can help the Saudi college students, who feel isolated, lost or stuck, get back their hopes and help them to be on track again.

\section{OBJECTIVES}

This study was initiated from the eagerness of two experienced EFL teachers who wanted to help the second language (English) learners in the Department of English, at King Khalid University, to be aware of the role of the two types of motivation: intrinsic and extrinsic in the second language learning process, as proposed by Deci and Ryan (1985). "Intrinsic motivation is the motivation to do something for its own sake, for the sheer enjoyment of a task. Extrinsic motivation is the motivation to do something in order to attain some external goal or meet some externally imposed constraint" (Hennessey et al., 2015). An example of the former is when students start enjoying their new language leaning journey while in the latter case, they feel motivated only to earn the certificate of accomplishment which may help them secure a job.

\section{HYPOTHESIS}

It is hypothesized that Saudi students in the Department of English at King Khalid University lack motivation due to the following reasons:

1. Lack of jobs after their graduation. 
2. Anxiety over their incompetence in English.

\section{MethodOLOGY}

This research followed the qualitative research methodology. Data was collected in two ways. First, through intensive personal interviews with 20 students from four sections of level 4 and two sections of level 8 in the Department of English. Then a survey (See Appendix) was conducted on 90 (ninety) students chosen from both level 4 and level 8 , to see their general reactions to the inquiries regarding both the intrinsic and extrinsic motivational issues.

\section{LITERATURE REVIEW}

Although a lot of literature can be found discussing extrinsic and intrinsic motivation and other related topics, the researchers of this paper did not find, even after extensive searches, satisfactory number of researches on the subject of this paper that had been conducted in the past.

Motivation is defined by Dörnyei and Ushioda (2011) as "what moves a person to make certain choices, to engage in action, to expend effort and persist in action".

Dörnyei (1998) tried to define it as the "dynamically changing cumulative arousal in a person that initiates, directs, coordinates, amplifies, terminates, and evaluates the cognitive and motor processes whereby initial wishes and desires are selected, prioritized, operationalized and successfully or un- successfully acted out.”

\section{DEFINITIONS OF INTRINSIC AND EXTRINSIC MOTIVATION}

Bernazzani (2017) sees that intrinsic motivation involves doing something because it's personally rewarding to you. Extrinsic motivation involves doing something because you want to earn a reward or avoid punishment.

Raffini (1996) has identified enjoyment as another relevant factor, arguing that students need to experience enjoyment in the learning process in order to feel intrinsically motivated. The same author discusses the interpersonal factor competence and assumes that in order to increase the intrinsic motivation among students it is important to create an environment in which students can discover that their serious effort toward learning enables them to attain a sense of academic competence. The author further suggests that despite the fact that the amount of time and effort required for academic achievement varies considerably among students, they all need to experience the feeling of competence that comes from achievement. (Raffini, 1996).

There are numerous studies aimed at determining the influence of motivation on the acquisition of a foreign language. Al-Tamimi and Shuib (2009) published their research on the motivation and attitudes of students of the Petroleum Engineering studies towards learning English at Hadhramaut University of Sciences and Technology, Yemen. The result of their research, which included three motivational constructs (instrumental, integrative and personal), showed the dominant role of instrumental motivation among students for learning English, although personal motivation was also noticeable.

Tremblay and Gardner's (1995) proposed integrative and instrumental motivation model that stresses the value of goals as the reasons for individual learners' successes or failures. Another model is the intrinsic-extrinsic dichotomy of self-determination theory developed by Deci and Ryan (1985). This theory emphasizes that a learner's learning goals can be influenced by pleasure, external rewards and even the feeling of regulation.

Al-Amr (1998), for instance, acknowledges that there are a number of valid reasons why instrumental motivation would be much more relevant in the Saudi setting than integrative motivation, not least because the second language is being learned away from the target language speakers and their culture.

Ryan and Deci (2000), state that extrinsic rewards can decrease intrinsic motivation. Rewards linked to the completion of a task, threats, deadlines and directives undermine intrinsic motivation because individuals perceive them as behavior control techniques.

Intrinsic motivation is defined commonly as driving forces of behavior that individuals deem inherent to the activities undertaken - namely, the activities themselves being interesting, enjoyable, and meaningful - in contrast to nonintrinsic forces in terms of incentives or pressure (e.g., rewards or deadlines) that are external to the activities.

\section{AnAlysis of the StUdENTS' RESPONSES}

\begin{tabular}{|l|l|l|}
\hline 1.Why did you join the Faculty of Languages and Translation at KKU? & 3 \\
\hline 1. The name and fame of the Faculty of Languages and Translation at KKU & $3 \%$ \\
\hline 2. My personal desire to study English & 30 & $33 \%$ \\
\hline 3. There was no other choice for me & 45 & $50 \%$ \\
\hline 4. To get a better job after graduation & 44 & $49 \%$ \\
\hline
\end{tabular}




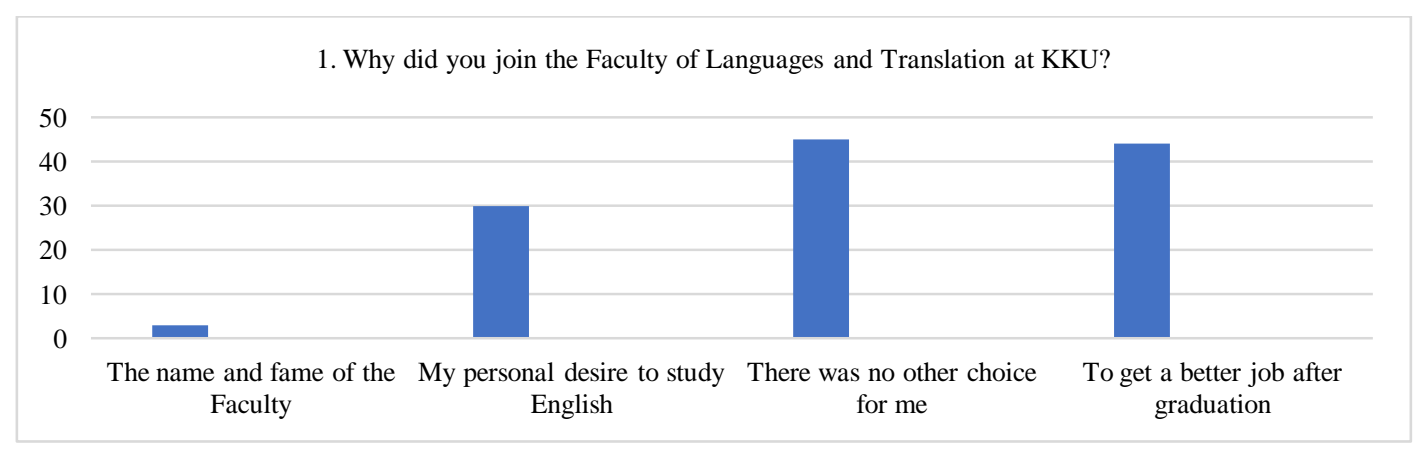

Comments:

The aim of this question was to shed light on the students' motivation at the Faculty of Language and Translation. The students' responses indicate that the number of students who joined the Department of English because there were no other choices for them outnumber those who joined this Department due to their personal desire to study English. That means, there are many students who were not planning to study English but for one reason or the other, they ended up enrolling at the Faculty of Languages and Translation. Moreover, there are some students who enrolled at the faculty just to get a good job after their graduation. Those students definitely will have an extrinsic rather than an intrinsic motivation for studying English.

\begin{tabular}{|l|l|l|}
\hline 2. Do you feel satisfied as a student of English? & 23 & $25 \%$ \\
\hline 1. Yes, to a great extent & 48 & $53 \%$ \\
\hline 2. To some extent & 11 & $12 \%$ \\
\hline 3. No, I am not satisfied & $8 \%$ \\
\hline 4. I cannot decide & $9 \%$ \\
\hline
\end{tabular}

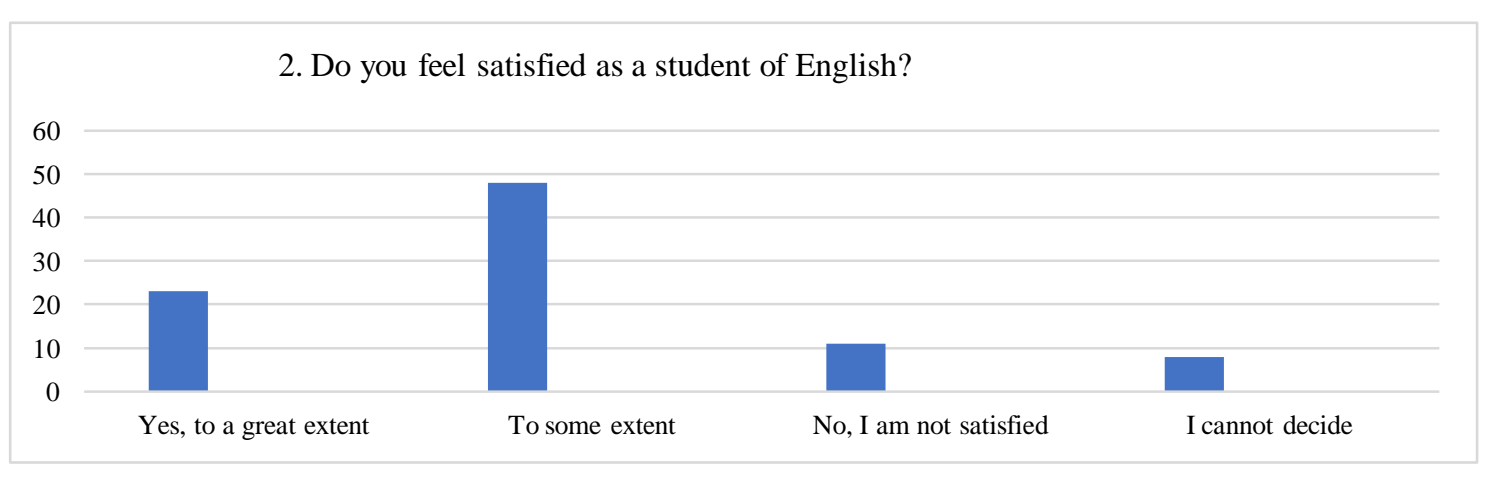

Comments:

Students' responses to the second question indicate that most of the students are not fully satisfied as students in the Department of English. The responses "to some extent" show indirectly the students' dissatisfaction as a result of being unable to join the colleges of their choice. Some students clearly express their dissatisfaction by selecting "No, I am not satisfied". There are some students who express their neutrality by selecting "I cannot decide", but it can be understood as a negative sign of their dissatisfaction of joining the Faculty of Language and Translation.

\begin{tabular}{|l|l|}
\hline 3. What were your motives when you joined this college? & 50 \\
\hline To find a better job & 45 \\
\hline To be able to communicate in English & $50 \%$ \\
\hline To acquire new knowledge for my future profession & $41 \%$ \\
\hline To be able to pursue my higher studies abroad & $14 \%$ \\
\hline
\end{tabular}




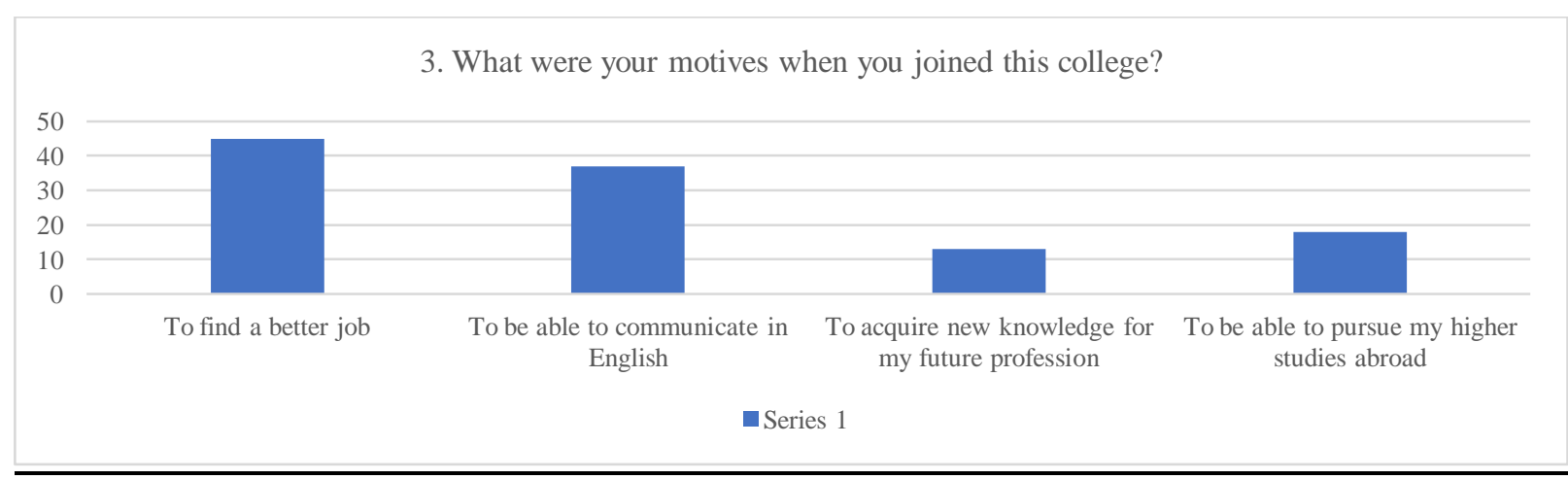

Comments:

This particular query yielded interesting responses. The bar graph above depicts that more than $40 \%$ of participants choose the first option, to find a better job after graduation. This clearly indicates that almost half of the respondents were influenced by their extrinsic motivation joining this college- as they hoped to find jobs with a KKU (King Khalid University) certificate that will guarantee a better future. The second highest bar, that represents the query: to be able to communicate in English, also confirms more extrinsic than intrinsic viewpoint from the participants.

\begin{tabular}{|c|c|c|}
\hline \multicolumn{3}{|c|}{ 4. Do you feel like attending your classes on daily bases? } \\
\hline Yes, all the classes & 10 & $11 \%$ \\
\hline Yes, most of the classes & 38 & $42 \%$ \\
\hline Yes, some classes only & 43 & $48 \%$ \\
\hline Yes, some classes only & 9 & $10 \%$ \\
\hline
\end{tabular}

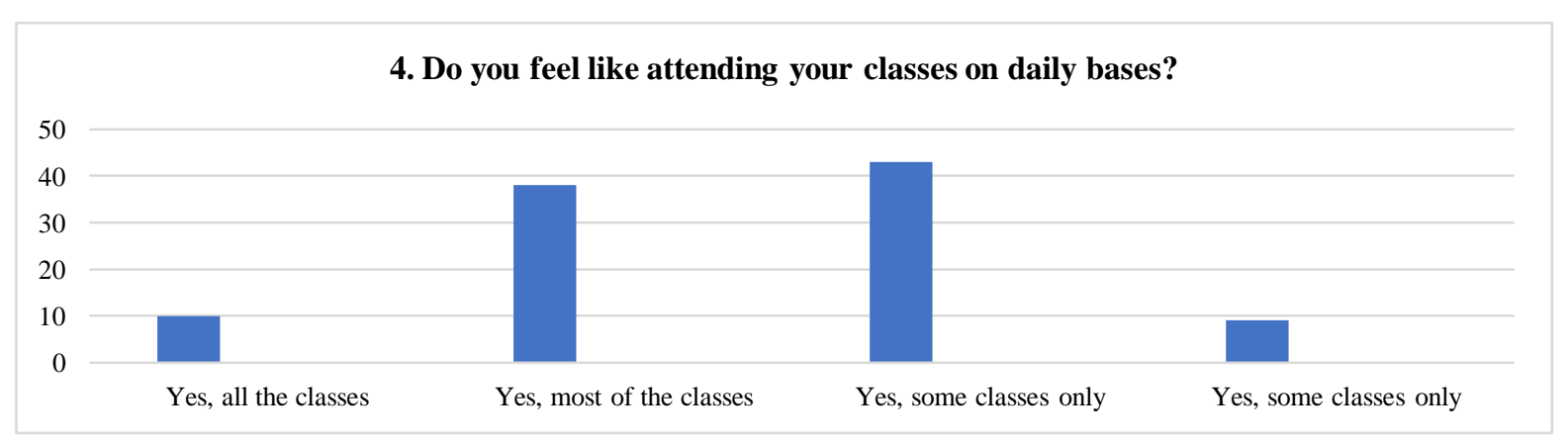

\section{Comments:}

More than forty percent of the survey takers said that they wanted to attend only some selected number of classes instead of all scheduled classes daily. While the given intrinsic option (first from the left) attracts only ten percent of total responses, our extrinsic option (third from the left) again scored high in the chart above.

\begin{tabular}{|l|l|}
\hline 5. If there was no absence register, will you attend classes? & 39 \\
\hline I will attend once or twice a week maximum & $43 \%$ \\
\hline I will attend all classes regularly every day & 25 \\
\hline I will attend one or two classes after 10 a.m. & $28 \%$ \\
\hline I will attend the midterm and final examinations only & 32 \\
\hline
\end{tabular}

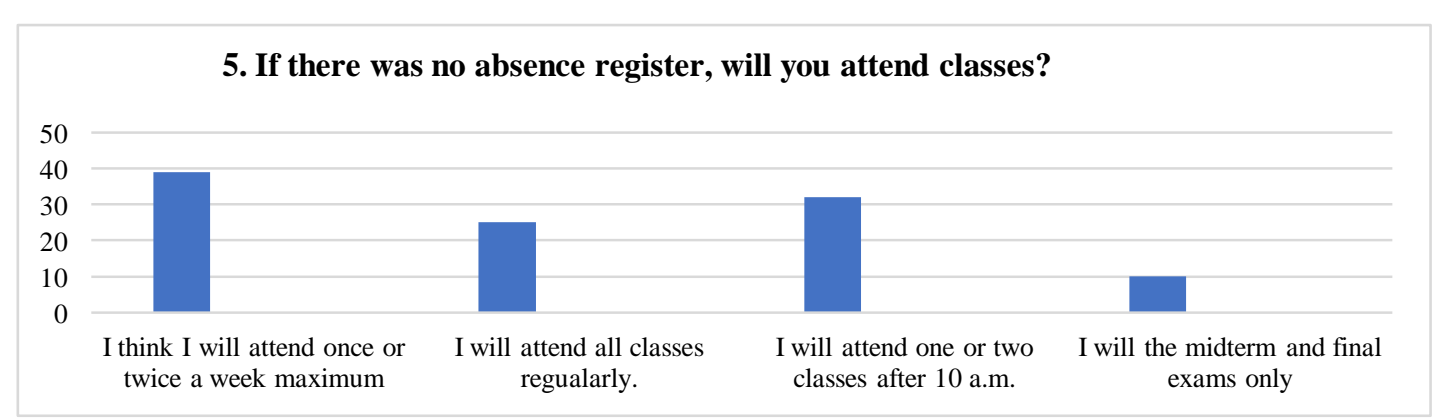

\section{Comments:}

When asked whether they would still attend lectures regularly, even in the absence of any absence register, almost forty percent students chose the option\# 1- that says, "I think I will attend once or twice a week maximum". This tells us that majority of the students were not motivated to come to the college only for the learning's sake; rather they'd just 
attend the number of classes that would retain their studentship. This only confirms their extrinsic motivational drivewhich is in sharp contrast with the option\# 2 (intrinsic in nature) that received only twenty-five percent of all responses.

\begin{tabular}{|l|l|l|}
\hline 6. Do you practice Your English outside the class? & 42 & $47 \%$ \\
\hline I don't speak English outside the class & 8 & $9 \%$ \\
\hline I speak English with some of my classmates only & 44 & $49 \%$ \\
\hline I chat with my friends online & 11 & $12 \%$ \\
\hline I speak English frequently after classes & \\
\hline
\end{tabular}

\section{Do you practice Your English outside the class?}

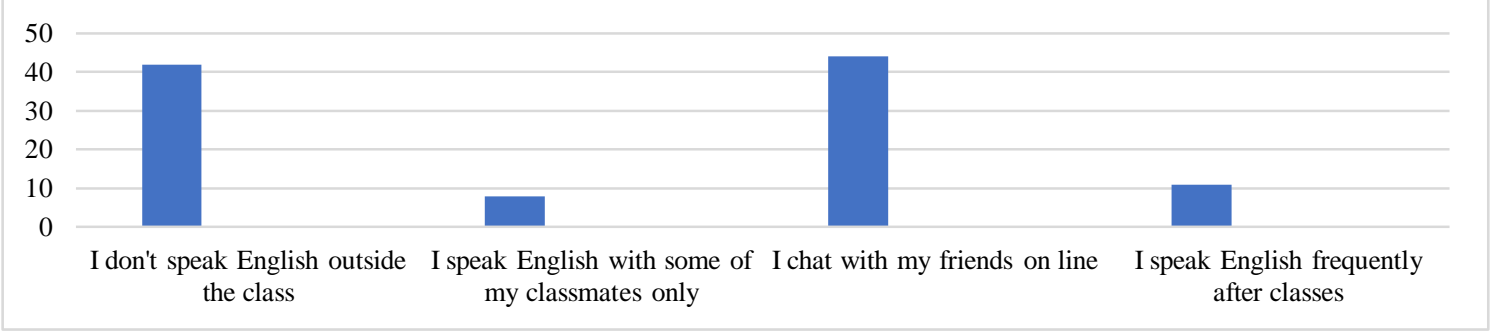

\section{Comments:}

While responding to the above-mentioned question, the two of our extrinsic choices (options \# $1 \& 3$ ) registered towering blocks of nearly forty five percent and more than forty percent respectively of the total responses. Unfortunately, this sheer extrinsic reply only reaffirms our preconceived assumption that our students are not doing enough speaking practice which they are in dire need to do.

\begin{tabular}{|l|l|l|}
\hline \multicolumn{2}{|c|}{ 7. Do you still feel like joining another college? } & $33 \%$ \\
\hline If I have the chance, I will join another college & 30 & $47 \%$ \\
\hline I think it is too late at this time & 42 & 48 \\
\hline I will definitely finish my English studies in this college & 25 & $28 \%$ \\
\hline I cannot decide at the time being & 5 & $6 \%$ \\
\hline
\end{tabular}

7. Do you still feel like joining another college?

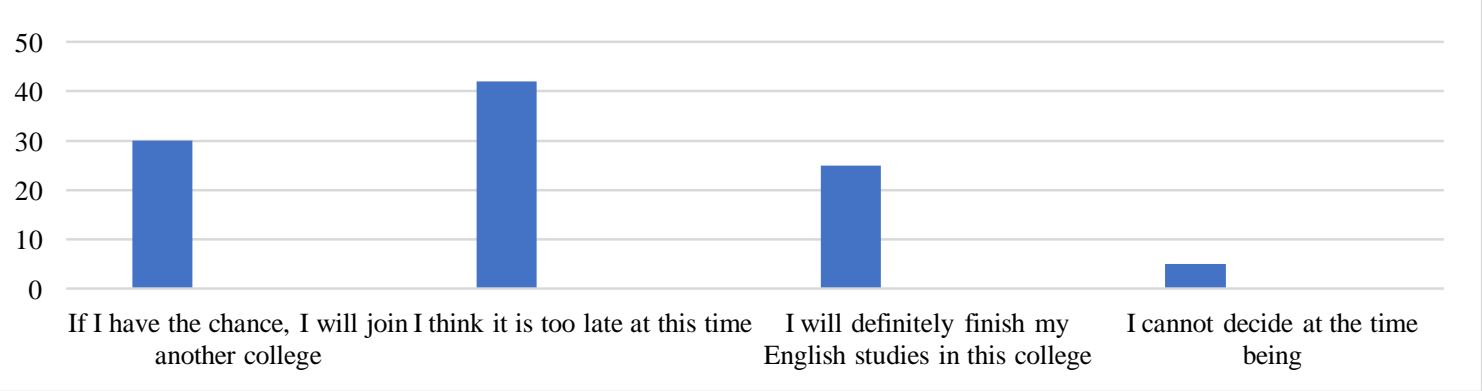

\section{Comments:}

Students, who were invited to take part in this survey, represent higher levels of study ranging from level 4 to level 8. Although, some of them are in the mid-levels while the others are in the last levels of their college education, surprisingly enough, they wished to change their current institution if they had had the chance. An astounding number (above 30\%) of the students stated that. While the biggest bar in the chart above soars past $40 \%$ mark, which tells about their lamentation that now it's too late to make the move- should not surprise anyone.

\begin{tabular}{|l|l|l|}
\hline 8. Was English your first choice when you joined KKU? & 3 & $3 \%$ \\
\hline No, but that was my parents desire & 32 & $36 \%$ \\
\hline Yes, it was my first choice from the beginning & 41 & $46 \%$ \\
\hline No, I was planning to join another college & 10 & $11 \%$ \\
\hline No, but low grades didn't allow me to join my colleges of choice & 10 \\
\hline
\end{tabular}




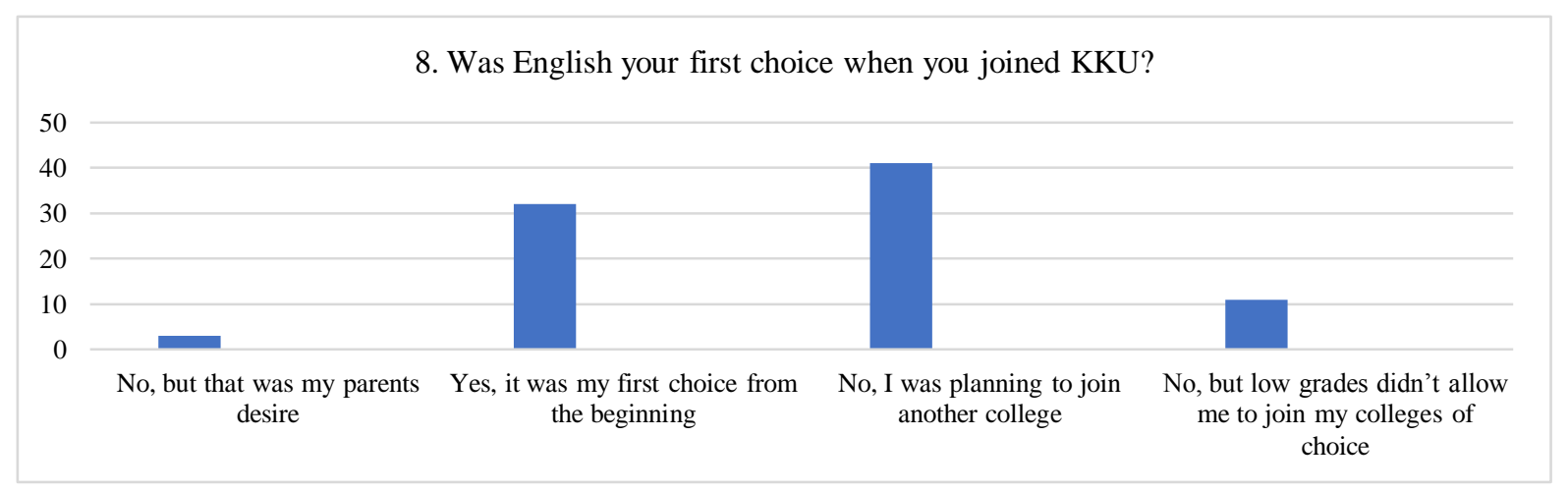

\section{Comments:}

Was English your first choice when you joined KKU? In reply to this question, only just over 30\% learners responded that yes, it was their first choice. In contrast, almost over $40 \%$ of them said no, English was not their first priority. Now, interestingly if we take into account another $10 \%$ of the responders- who also said no, but because of their low GPAs they had no other options left except to join this college- then the total number of students who reluctantly joined this college, would go well above $50 \%$ mark.

\begin{tabular}{|l|l|}
\hline 9. Do you think you will find a better job after graduation? & $4 \%$ \\
\hline I am working with my fathers' firm & 4 \\
\hline I have a part time job at the time being & $17 \%$ \\
\hline I am planning to pursue my higher studies & $33 \%$ \\
\hline I don't think I will find a job after my graduation & 30 \\
\hline
\end{tabular}

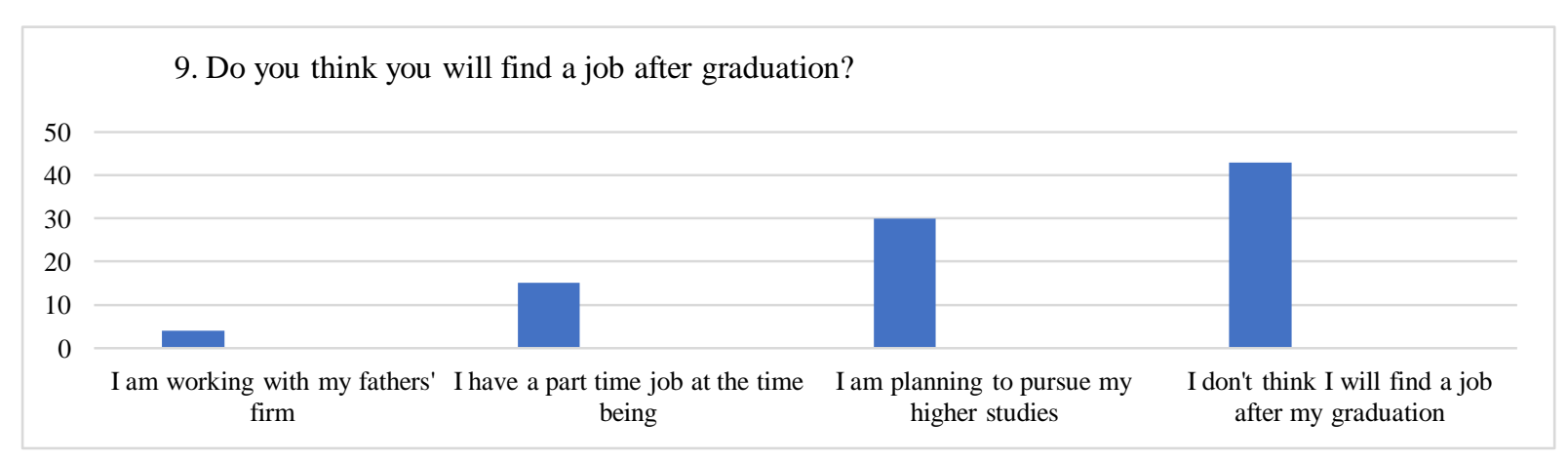

\section{Comments:}

As we are moving towards the end of this survey questions, the frustration and disappointment of our future graduates are becoming clearer. Here, in the chart above, we can see that almost $45 \%$ of the respondents admit that they don't think they would be able to get a job after their graduation.

\begin{tabular}{|l|l|}
\hline 10. What was the college that you wanted to join? Specify the college. & 39 \\
\hline 1. Language and Translation & $43 \%$ \\
\hline 2. Business and Administration & 19 \\
\hline 3. Engineering & $21 \%$ \\
\hline 4. Medicine & $13 \%$ \\
\hline
\end{tabular}

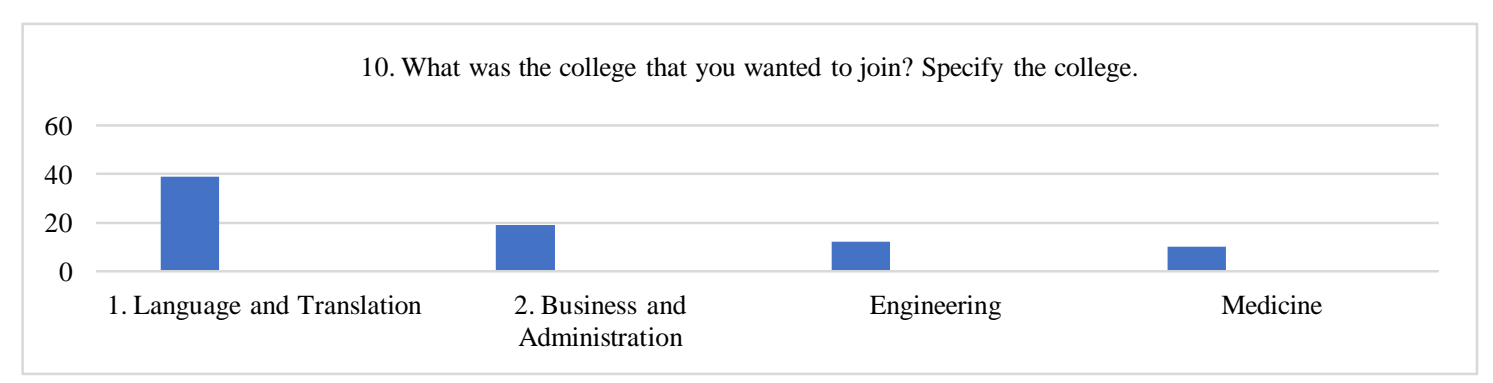

\section{Comments:}

Finally, this last query investigates students' original desire to join the college of their choice. Although $40 \%$ of them have joined their desired college, (i.e., the faculty of Languages and Translation), we must not forget that a huge $60 \%$ of their peers were met with disappointment as they couldn't join their dream college for some reason or the other. 


\section{ANALYSIS}

The study that was conducted with almost a hundred students (90 male students from the Department of English were randomly selected for this study), unfortunately, depicts a rather sorry picture of the untold stories of our college students' academic journey into the realm of higher studies. Although, it is no way the reflection of the whole student body of King Khalid University as a whole or Saudi Arabia in general, it certainly, at the same time, mirrors most of the Saudi college students' disappointments, frustrations and lack of an intrinsic or true motivation in their academic life. If we look at the survey responses closely, we will see a pattern that clearly tells us that our students are struggling in their academic endeavors. It all started with a big mistake that was somehow committed in the early days of a student's college life- when he unwillingly joined a college that was not his first choice (Fig. 1). The choice was made either to satisfy a worrying parent as, "sometimes parents are so curious about their child's education and career that they keep reminding and injecting in the minds of their child that education is the only solution to future miseries" (Afzal et al., 2010) or simply because there were no other options available but to join this faculty. This is the reason almost half of the learners who were interviewed and surveyed said they were satisfied for being at this college only to some extent (Fig.2). And if we take into account other two responses, no, I am not satisfied and I cannot decide, the overall non satisfactory responses would cross past $70 \%$ mark. Once joined, the college students are now hopeful that at least a certificate from a renowned university would compensate their wrong choice by guaranteeing confirmed job placements after graduation. About $30 \%$ of the respondents say they want to improve their English and be able to communicate in English, which shows an intrinsic motivational trend, although more than $30 \%$ of their peers want to acquire their future job related knowledge and to study abroad to ensure securing a good job in the future- certainly highlights the extrinsic motivational force behind these choices.

Question 4 enquires about the students' spirit for attending all the lectures on a regular basis, something which is highly anticipated from a serious learner. But unfortunately, enough, only $10 \%$ of the students nodded positively in reply of that query. It is noteworthy that although a little more than $35 \%$ of them say that they would probably attend some classes, a little less than $45 \%$ students confessed that they would in fact consider attending only some selected lecture of importance- that tells us clearly that the type of motivation responsible here is truly extrinsic by nature. The next question is somewhat related to the last one. Figure5, depicts an uncomfortable fact that a mere $25 \%$ of our students would remain motivated positively on intrinsically even if there was no absence register. While a towering $40 \%$ students say that they would only attend one or two classes per week, a staggering above $30 \%$ of them say they will join only the lectures that start after 10 a.m. in the morning. A third say they would only appear in the midterms and the finals. The overall impression is genuinely extrinsic. This is supported by another research study done by Tom Clay and Lori Breslow (2006) where they found that: "When asked to estimate what percentage of their lectures they attend, about two of every three respondents $(67 \%)$ estimated that they attend at least $90 \%$, three of every four (76\%) that they attend at least 75\%, and more than nine in 10 (93\%) that they attend at least half." (Clay. T., \& Breslow. L. 2006).

Many a time, we see the instructors complain a lot about students having very little or no practice in English at all. Figure\# 6 might help us to understand some of the reasons behind this problem, that otherwise would remain obscure or hidden. Here more than $40 \%$ participants admit that they do not practice English outside of their classes, while the tallest bar shows that almost $45 \%$ students use the language only in social media interactions, which is in a sense, not very encouraging. For educators this is not the ideal or authentic mode of learning English language but certainly not surprising, as some researchers (Walubita, \& Akakandelwa, 2018; Grusec, \& Hastings, 2007) think it is mainly the social media and its virtual world that could stand behind this eccentric result. Watching English videos and films is the most accessible and the most practiced by the students and it recently takes the place where the family should be. (M. Alaraj. M, 2019) Just a little over 10\% of the students are found to be practicing English outside the classrooms.

Students, who were invited to take part in this survey, were from higher levels of study- ranging from level 4 to level 8- last level at this college. Yet to our utmost surprise and shock, reply to this particular question explicitly tells us that more than $40 \%$ of our current students feel that it is now too late to change this college and to join another one. Other $30 \%$ say that they still long for joining their college of choice if there was a possibility.

Figure\#8 reveals another negative result which shows that studying English was the first choice of a mere $30 \%$ of our students, at the time of joining the university. And as predicted, rest of the students admitted that one way or the other English was not on the top of the list of their subject choices- only confirms the prevailing extrinsic motivational attitude.

Finally, the answers to the last question of this survey are no exceptions when the students were asked to name the college / faculty that they hoped to join at the first place. Once again, less than half of the total student body joined their chosen college, i.e., English, and the majority of their classmates were not so lucky.

The overall outcome of this initiative, which was aimed at finding the inner working of our students' motivational drive, completely aligns with the researchers' hypothesis that, most of the students, if not all of them, in the Department of English of this Saudi university-are strongly motivated extrinsically rather than intrinsically. A combined teaching experience of 50+ years, of both the researchers, was already witnessing and observing these findings- which are only now being proved authentic with this survey. The result of this survey in particular and the current study in general partially allows us a rare opportunity to have a glimpse on the psychology of a group of Saudi college students who are 
pursuing their higher studies unhappily, unwillingly and uncertainly which ultimately lead to their academic failure mostly since the learners' anxiety level plays an essential role in language achievement. (Mohammed, 2015)

The table below is a fact sheet from the Faculty of Languages and Translations' registrar's office that shows how many students enrolled in the four previous semesters ranging from 2017-2018 sessions to 2018-2019 sessions. What is interesting to notice here is that roughly about $20 \%-30 \%$ of those enrolled students either became deprived or chose to drop out from a course. So, this staggering number of students who did not complete the course, either by their own choice or being forced by any difficult circumstances, supports the researchers' hypothesis that as they were driven mostly by their extrinsic motivational factors and they ultimately lost their spirit of academic success after some time and left the journey in the midway. This is not something normal if we consider the fact that each university student here receives an amount of little more than \$250 a month just for attending his college regularly.

\begin{tabular}{|l|l|l|l|l|l|}
\hline Academic Year & $\begin{array}{l}\text { Number of } \\
\text { Enrolled } \\
\text { Students }\end{array}$ & $\begin{array}{l}\text { Number } \\
\text { Withdrawn Students }\end{array}$ & $\begin{array}{l}\text { Number } \\
\text { Deprived Students }\end{array}$ & $\begin{array}{l}\text { Total } \\
\text { +Deprived students }\end{array}$ \\
\hline $\begin{array}{l}2017-2018(1439-1440 \text { Hijri) } \\
1^{\text {st }} \text { Semester }\end{array}$ & 1004 & 172 & 56 & 228 & $22.7 \%$ \\
\hline $\begin{array}{l}2017-2018(1439-1440 \text { Hijri) } \\
2^{\text {nd }} \text { Semester }\end{array}$ & 1073 & 160 & 40 & 200 & $18.6 \%$ \\
\hline $\begin{array}{l}2018-2019(1440-1441 \text { Hijri) } \\
1^{\text {st }} \text { Semester }\end{array}$ & 1002 & 184 & 59 & 243 & $24.2 \%$ \\
\hline $\begin{array}{l}2018-2019(1440-1441 \text { Hijri) } \\
2^{\text {nd }} \text { Semester }\end{array}$ & 1020 & 234 & 65 & 299 & $29.3 \%$ \\
\hline
\end{tabular}

\section{CONCLUSION}

In the light of the findings from the collected data, it can be seen that the majority of the students suffer from lack of intrinsic motivation as they are found to be driven only by different extrinsic motivational factors, that seems to be the mere reasons for the students who enroll in the English Language programs in the department of English, King Khalid University, in Saudi Arabia. The authors of this paper strongly believe that Saudi college students in general are in dire need for proper guidance and encouragement from their family and friends, teachers and peers for both enjoying their academic endeavors and in preparing themselves for the future challenges. The results of this study shows that by taking certain steps such as building their awareness, making them realize the importance of learning a second language, in this case, English, regardless of the need for securing a job etc. - we can initiate a positive change in the mindsets of these Saudi college students to make them feel more motivated intrinsically than ever before and help them become successful in both academic and professional arena.

This study deals with the male Saudi college students at King Khalid University. One shortcoming that this research project reports is that, it was not possible, at that time, due to limited access and availability of opportunities, to include the female Saudi students studying at King Khalid University's female only campuses, in the current study, which would have allowed this research study to focus on a much broader aspect of the issue.

\section{RECOMMENDATIONS}

The writers here would like to recommend that these Saudi college students should be mentored at one point or another during their four- year long engagement in acquiring a second language in a quite challenging academic environment. They also think that establishing a counselling center in the Department of English at King Khalid University for its thousands of students to address their academic, personal issues, difficulties etc. that they face on a regular basis. Such initiatives, no doubt, will go a long way to help students feel more confident, focused, and most importantly stay positively motivated throughout their academic life. It is worth mentioning that the earliest they come to know the differences between the intrinsic and extrinsic motivational types, the better they will be to look at their academic engagements with a new outlook that is more intrinsic by nature than extrinsic, which at later stages, might help them place themselves at superior professional positions. As the researchers mentioned before, the topic of this paper appears to be quite a new area of research that has not yet been explored much, this requires, both locally and internationally, further research with deeper investigation.

\section{APPENDIX. QUESTIONNAIRE}

Dear Students,

This questionnaire aims at understanding the students' motivation for studying English at the Faculty of Languages and Translation at King Khalid University. We would like to assure you that the information obtained will be used for academic purposes only, and will be very confidential. Thank you very much for your cooperation and participation in this study.

Please choose only one answer that you think is appropriate in your situation.

أعزائي الطلبة، 


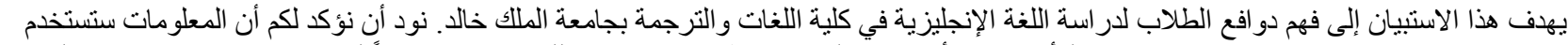

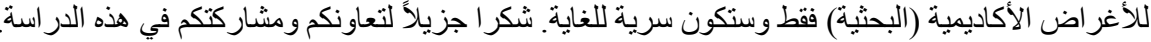

الرجاء اختيار إجابة واحدة فقط والتهي تعتقد أنها مناسبة.

1. Why did you join the Faculty of Languages and Translation at KKU?

The name and fame of the Faculty of Languages and Translation.

My personal desire to study English.

There were no other choices for me.

To get a better job after graduation.

2. Do you feel satisfied as a student of English?

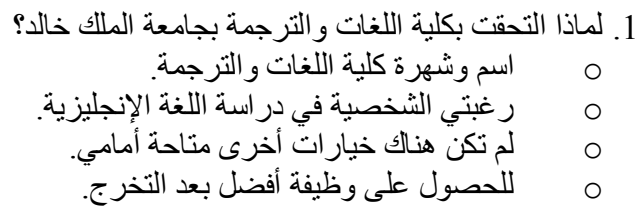

Yes, to a great extent.

Yes, to some extent.

No, I am not satisfied at all.

I cannot decide.

3. What were your motives when you joined this college?

$$
\begin{aligned}
& 2 \text { هل نشعر بالرضا كطالب لدراسة اللغة الإنجليزية؟ } \\
& \text { O } \\
& \text { O } \\
& \text { O } \\
& \text { م أستطيع أن أقرر. }
\end{aligned}
$$

To find a better job after graduation.

To be able to communicate in English.

To acquire new knowledge for my future profession.

To be able to pursue my higher studies abroad.

4. Do you feel like attending your classes on daily bases?

Yes, all the classes.

Yes, most of the classes.

Yes, some classes only.

No, I don't feel like attending classes at all.

5. If there was no absence register, will you attend classes?

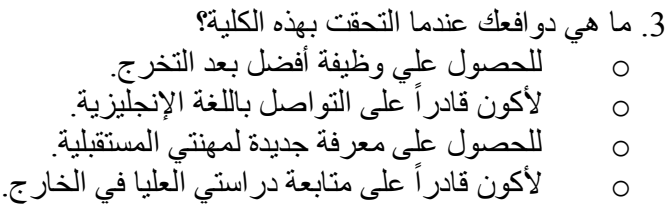

O الأكون قادر اً على متابعة در استي العليا في الخار ج.

I think I will attend once or twice a week maximum.

I will attend all classes regularly every day.

I will attend one or two classes after 10 a.m.

I will attend the Midterm and final examinations only.

$$
\begin{aligned}
& \text { 4. هل تر غب في حضور المحاضر ات بومياً؟ }
\end{aligned}
$$

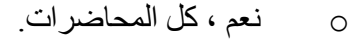

$$
\begin{aligned}
& \text { O }
\end{aligned}
$$

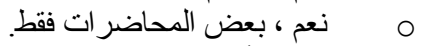

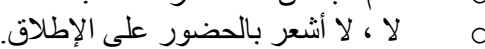

6. Do you practice your English outside the class?

I don't speak English outside the class.

I speak English with some of my classmates only.

I chat with my friends on line.

I speak English frequently after classes.

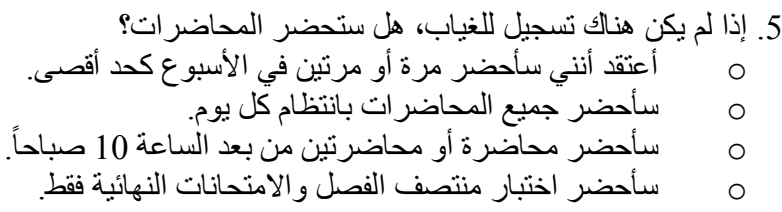


7. Do you still feel like joining another college?

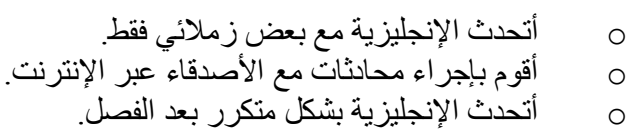

If I have the chance, I will join another college.

I think it is too late at this time.

I will definitely finish my English studies in this college.

I cannot decide at the time being.

8. Was English your first choice when you joined KKU?

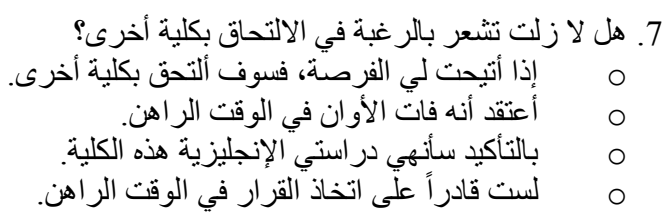

No, but that was my parents desire.

Yes, it was my first choice from the beginning.

No, I was planning to join another college.

No, but my low grade didn't qualify me to join my colleges of choice.

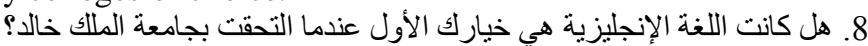

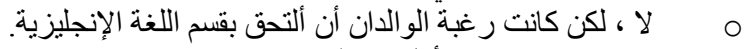

$$
\begin{aligned}
& \text { O }
\end{aligned}
$$

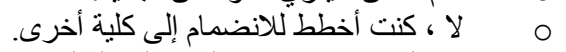

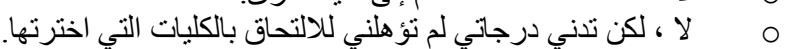

9. Do you think you will find a job after graduation?

I am working with my father's firm?

I have a part time job at the time being.

I am planning to pursue my higher studies.

I don't think I will find a job after my graduation.

10. What was the college that you wanted to join at KKU?

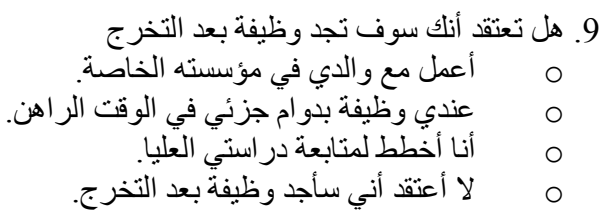

Specify the college

10. ما هي الكلية التي كنت ترغب الالتحاق بها في جامعة الملك خالد؟

\section{REFERENCES}

[1] Afzal, H., Ali, I., Aslam Khan, M., \& Hamid, K. (2010). A Study of University Students' Motivation and Its Relationship with Their Academic Performance. Available at SSRN 2899435.

[2] Akakandelwa, A., \& Walubita, G. (2018). Students' social media use and its perceived impact on their social life: A case study of the University of Zambia.

[3] Al-Amr, B. (1998). Attitudes, motivation, and socio-cultural effects on English foreign language learning and proficiency: the Saudi Arabian context. Unpublished MA thesis, University of Essex, Essex.

[4] Al-Tamimi A., \& Shuib, M. (2009). Motivation and attitudes towards learning English: A study of petroleum engineering undergraduates at Hadhramout University of Sciences and Technology. GEMA Online Journal of Language Studies. 9(2):29-55.

[5] Bernazzani, S. (2017). https://blog.hubspot.com/maketing/intrinsic-and-extrinsic-motivation. Retrieved on Dec 12, 2019.

[6] Crotty, J. M. (2013). Motivation matters: 40\% of high school students chronically disengaged from school. Retrieved from Forbes http://onforb. es/10G5S0t. Retrieved on Dec.12, 2019.

[7] Clay, T., \& Breslow, L. (2006). Why students don't attend class. MIT Faculty Newsletter, 18(4). Retrieved on Dec. $12,2019$.

[8] Deci, E., \& Ryan, R. (1985). Intrinsic motivation and self-determination in human behavior. (New York: Plenum).

[9] Dörnyei, Z. (1998). Motivation in second and foreign language learning. Language Teaching. 1998; 31(3):117-35.

[10] Dörnyei, Z. (2005) The psychology of the language learner: Individual differences in second language acquisition. Lawrence Erlbaum, Mahwah, NJ.

[11] Dörnyei, Z., \& Ushioda, E. (2009) (Eds.), Motivation, language identity and the L2 self, Multilingual Matters, Bristol, Buffalo, Toronto (2009), pp. 9-42

[12] Dörnyei, Z., \& Ushioda, E. (2011). Teaching and researching motivation. Harlow, England.

[13] Gardner, R.C., Day, J.B., \& Maclntyre, P.D. (1992). Integrative Motivation, Induced Anxiety, and Language Learning in a Controlled Environment. Studies in Second Language Acquisition, 14(2), 197-214.

[14] Grusec, J. \& Hastings, P. (2007). Handbook of Socialization, 208-231. New York: Guilford. Journal of Business and Management, 5(4). https://doi.org/10.5539/ijbm.v5n4p80. Retrieved on Nov. 19, 2019. 
[15] Hennessey, B., Moran, S., Altringer, B., \& Amabile, T. M. (2015). Extrinsic and intrinsic motivation. Wiley encyclopedia of management, 1-4.

[16] James Marshall Crotty. www.Forbes.com/ Mar.13, 2013. Retrieved on Dec. 12, 2019.

[17] M. Alaraj, M. (2019). An Analysis into the Outside Classroom Opportunities for Practicing Oral English and Their Effect on EFL Learners' Fluency. International Journal of Language \& Linguistic, 6(4). https://doi.org/10.30845/ijII.v6n-4p17 Retrieved on Jan. 05, 2019.

[18] Mohammed, A. (2015). EFL Effective Factors: Anxiety and Motivation and their Effect on Saudi College Student's Achievement. Arab World English Journal, 6(2), 201-218. https://doi.org/10.24093/awej/vol6no2.16 Retrieved on Jan. 05,2019.

[19] Raffini, J.P. (1996). 150 ways to increase intrinsic motivation in the classroom. Prentice Hall. U.S.

[20] Scovel,T. (1978). The Effect of Effect on Foreign Language Learning: A Review of The Anxiety Research. Language Learning, 28(1), 129-142. https://Doi.org/10.1111/J.1467-1770.1978.Tb00309.X Retrieved on Feb. 23,2020. Retrieved on Jan. 05, 2019.

[21] Tremblay, P.F., \& Gardner, R.C. (1995). Expanding the motivation construct in language learning. The Modern Language Journal, 79(4), 505-518.

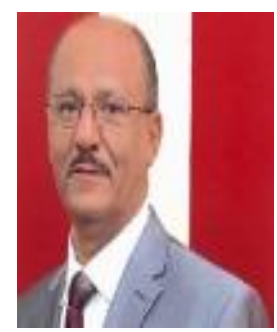

Rafiq Al-Shamiry is currently an associate professor of English Language Teaching (ELT) at the Faculty of Languages and Translation, King Khalid University, Kingdom of Saudi Arabia. He has taught English for 15 years in Ibb University, Yemen. He has worked for the Ministry of Education as a chief inspector of English for 10 years. He has obtained his post graduate diploma in Applied Linguistics, Moray House, College of Education (UK). His master's degree in applied Linguistics, Leeds University, School of Education (UK). His Ph.D. in Applied Linguistics, C.I.E.F.L. Hyderabad, India. His interests are applied linguistics issues in language teaching.

Mohammad Al Fuad works as a lecturer in English at the Faculty of Languages and Translation, King Khalid University, Kingdom of Saudi Arabia. He has a MA in English degree from the National University, Bangladesh. He has 14 years of teaching experience as a lecturer. His research interests are teacher-student relationships, motivational issues in students and language learning related issues. 